Jurnal Penelitian dan Evaluasi Pendidikan

\title{
EVALUASI KINERJA GURU SEKOLAH MENENGAH KEJURUAN SUMATERA BARAT PASCASERTIFIKASI
}

\author{
Ramli, Nizwardi Jalinus \\ Fakultas Teknik Universitas Negeri Padang \\ Jln. Prof. Dr. Hamka Air Tawar Padang \\ ramli_bakar76@yahoo.com
}

\begin{abstract}
Abstrak
Penelitian ini bertujuan untuk mengevaluasi (1) tingkat capaian UU no. 14 tahun 2005 tentang guru dan dosen, (2) beban mengajar guru SMK yang telah disertifikasi, dan (3) dampak sertifikasi terhadap kinerja guru di mata masyarakat. Metode penelitian yang digunakan deskriptif, populasi sebanyak 954 orang guru, sampel dipilih sebanyak 247 orang dengan teknik random sampling. Data dikumpulkan dengan angket dan dianalisis menggunakan teknik deskriptif. Hasil penelitian ini menunjukkan bahwa (1) secara umum guru SMK telah memenuhi kriteria UU No. 14 Tahun 2005 tentang Guru dan Dosen; (2) sebagian besar guru SMK telah memperoleh beban mengajar yang sesuai dengan yang ditetapkan pemerintah yaitu 24 jam tatap muka, dan (3) secara umum dampak sertifikasi relatif kecil terhadap kinerja guru, namun cukup baik terhadap kesejahteraan guru kejuruan.
\end{abstract}

Kata kunci: evaluasi, sertifikasi, kinerja guru SMK 


\title{
PERFORMANCE EVALUATION OF VOCATIONAL HIGH SCHOOL'S CERTIFIED TEACHERS IN WEST SUMATRA
}

\author{
Ramli dan Nizwardi Jalinus \\ Fakultas Teknik Universitas Negeri Padang \\ Jln. Prof. Dr. Hamka Air Tawar Padang \\ ramli_bakar76@yahoo.com
}

\begin{abstract}
This study was aimed to evaluate the achievement level of: (1) Law no. 14 of 2005 on teachers and lecturers, (2) the teaching load of vocational school teachers who have been certified, and (3) the impact of certification on the teachers' performance. The research used descriptive method. The population comprised 954 teachers, and sample of 247 people were selected with a random sampling technique. Data were collected by questionnaire and analyzed using descriptive techniques. The study found (1) the general vocational teachers had met the criteria of the law no. 14 of 2005 on teachers and lecturers. (2) the majority of teachers had acquired vocational teaching load in accordance with the government's full 24-hour face-to-face, and (3) in general, the impact of certification is relatively little on the performance of certified teachers, but good enough for the welfare of vocational teachers.
\end{abstract}

Keywords: evaluation, certification, vocational teacher performance 


\section{Pendahuluan}

Pada dasarnya terdapat berbagai faktor yang mempengaruhi keberhasilan pendidikan, antara lain: guru, siswa, sarana dan prasarana, lingkungan pendidikan, kurikulum. Di antara faktor tersebut, guru dalam kegiatan proses pembelajaran di sekolah menempati kedudukan yang sangat penting dan tanpa mengabaikan faktor penunjang yang lain, guru sebagai subjek pendidikan sangat menentukan keberhasilan pendidikan itu sendiri. Jalal (2007:1) mengatakan bahwa pendidikan yang bermutu sangat tergantung pada keberadaan guru yang bermutu, yakni guru yang profesional, sejahtera dan bermartabat. Oleh karena itu, keberadaan guru yang bermutu merupakan syarat mutlak hadirnya sistem dan praktik pendidikan yang bermutu.

Salah satu kebijakan yang dilakukan oleh pemerintah Republik Indonesia untuk meningkatkan mutu dan kinerja guru adalah melaksanakan sertifikasi guru sesuai dengan Undang-Undang No. 14 Tahun 2005 tentang Guru dan Dosen. Secara konseptual undang-undang tersebut telah menggariskan tentang kualifikasi dan kompetensi guru secara umum, bahwa guru minimal berkualifikasi sarjana (S1) atau diploma (D4) (pasal 9), disisi lain setiap guru secara ideal harus memiliki kompetensi dan sertifikasi profesi (pasal 10 dan 11). Apakah dengan memiliki sertifikasi, guru akan lebih meningkat kinerjanya? Pertanyaan ini penting untuk dievaluasi secara kritis, karena sertifikasi berkaitan dengan peningkatan mutu pendidikan. Sebagai perbandingan, di Amerika Serikat kebijakan sertifikasi bagi guru belum berhasil meningkatkan mutu kompetensi guru, hal ini dikarenakan kuatnya resistensi dari kalangan guru sehingga pelaksanaan sertifikasi berjalan amat lambat, dalam kurun waktu sepuluh tahun, mulai tahun 1997-2006, Amerika Serikat hanya menargetkan 100.000 guru untuk disertifikasi. Bandingkan dengan Indonesia yang dalam kurun waktu yang sama menargetkan mensertifikasi 2,7 juta guru. Sebaliknya, kebijakan yang sama telah berhasil meningkatkan mutu kompetensi guru di Singapore dan Korea Selatan (Jalal, 2007:2).

Program sertifikasi guru telah berlangsung sejak tahun 2006, ini berarti telah terlaksana lima angkatan. Pola pelaksanaan mulanya adalah portofolio dan dilanjutkan dengan PLPG bagi yang tidak lolos portofolio. 
Kemudian karena berbagai kendala, model portofolio dihilangkan, dan sampai saat ini model PLPG yang banyak digunakan. Terakhir, setiap guru yang telah mengikuti program PLPG diwajibkan untuk mengikuti uji kompetensi guru. Sampai akhir tahun 2012 hampir 1,2 juta guru telah di sertifikasi di seluruh Indonesia. Khusus untuk wilayah Sumatera Barat sampai tahun 2011 sudah sebanyak 32.962 orang guru yang telah berhasil memperoleh sertifikat, dan 2.799 orang di antaranya adalah guru kejuruan, yaitu guru-guru yang mengampu mata diklat bidang kejuruan. Realitasnya, saat ini sebagian guru kejuruan telah mendapat kesempatan untuk bersertifikasi guru profesi, dan dalam Undang-Undang No 14 Tahun 2005 tentang Guru dan Dosen ditonjolkan bahwa harga sertifikasi adalah tambahan gaji sebesar gaji pokok.

Implikasi sertifikasi guru terhadap kinerja guru di beberapa SMK memperlihatkan kecenderungan yang cukup baik. Ramli (2012) melakukan penelitian tentang kinerja guru teknologi dan kejuruan di Sumatera Barat. Ada kecenderungan tidak terdapat perubahan yang signifikan terhadap kinerja guru yang telah mengikuti program sertifikasi, lebih jauh diungkapkannya, bahwa kinerja guru yang bertugas di sekolah RSBI tidak berbeda secara signifikan dengan guru yang bertugas di SMKN. Kesimpulan ini menggambarkan bahwa sertifikasi ternyata relatif belum menggambarkan pengaruh terhadap peningkatan kinerja guru, walaupun dalam aturan ditetapkan bahwa guru yang telah memperoleh tunjangan profesi wajib mengajar 24 jam- 40 jam pelajaran per minggu (pasal 35 ayat 2.UU No. 14/2005).

Guru kejuruan dituntut untuk memiliki kemampuan yang bukan hanya mampu mengajarkan teori di kelas, namun mereka dituntut juga mampu mendidik, mengajar, melatih, dan membimbing peserta didiknya di tempat kerja, apakah itu di workshop, bengkel, laboratorium, serta membimbing peserta didik untuk mampu bekerja di dunia usaha dan industri dengan karier yang prospektif. Reformasi di bidang pendidikan guru kejuruan, menuntut perubahan karakter guru yang ada selama ini terbiasa dengan pola kepemimpinan instruksi, semua serba diatur dari atas, guru kehilangan kreativitas. Padahal untuk mampu bersaing di era global, yang 
serba canggih, era yang menuntut tingkat adaptasi yang tinggi terhadap perubahan, memerlukan guru yang mempunyai kinerja tinggi.

Nawawi (1996:15) menyatakan kinerja guru adalah kemampuan yang dimiliki oleh individu dalam melakukan suatu pekerjaan, sehingga terlihat prestasi pekerjaannya dalam menggapai tujuan. Subroto (1997:15) menyatakan kinerja merupakan kemampuan atau kecakapan guru dalam menciptakan suasana pembelajaran yang komunikatif antara guru dan peserta didik yang meliputi ranah kognitif, afektif dan psikomotorik. Hasil kerja yang ditampilkan guru dari serangkaian kemampuan yang dimiliki guru sebagai seorang profesional. Sementara itu Suharsaputra berpendapat bahwa kinerja guru adalah unjuk kerja guru dalam melaksanakan tugasnya sebagai pendidik. Bernardin \& Russell (2000) "Performance is defined as the record of outcomes produced on a specified job function or activity during a specific time period". Secara umum dapat disimpulkan bahwa unjuk kerja guru adalah kinerja guru yang bermakna hasil kerja proses pembelajaran yang dilaksanakan guru dalam interaksi pembelajaran antara guru dan peserta didik.

Undang-Undang No. 20 Tahun 2003 tentang Sisdiknas BAB XI pasal 39 ayat (2), menyatakan bahwa pendidik merupakan tenaga profesional yang bertugas merencanakan dan melaksanakan proses pembelajaran, menilai hasil pembelajaran, melakukan pembimbingan dan pelatihan serta melakukan penelitian dan pengabdian kepada masyarakat, terutama bagi pendidik pada perguruan tinggi. Undang-Undang No. 14 Tahun 2005 tentang Guru dan Dosen Bab IV pasal 10 ayat (1) menyatakan bahwa guru dituntut untuk menguasai 4 kompetensi utama yaitu kompetensi pedagogik, kompetensi sosial, kompetensi kepribadian dan kompetensi profesional. Pasal 20 (a) menyatakan bahwa standar prestasi kerja guru dalam melaksanakan tugas keprofesionalannya, guru berkewajiban merencanakan pembelajaran, melaksanakan proses pembelajaran yang bermutu serta menilai dan mengevaluasi hasil pembelajaran. Tugas pokok guru tersebut yang diwujudkan dalam kegiatan pembelajaran merupakan bentuk kinerja guru. Permendiknas No. 41 Tahun 2007 tentang Standar Proses untuk Satuan Pendidikan Menengah dijabarkan beban kerja guru mencakup kegiatan pokok, yaitu: (1) merencanakan pembelajaran; (2) me- 
laksanakan pembelajaran; (3) menilai hasil pembelajaran; (4) membimbing dan melatih peserta didik; (5) melaksanakan tugas tambahan.

Dalam melaksanakan pembelajaran, guru kejuruan yang sekarang pada dasarnya terdidik secara akademik sebagai guru kejuruan dengan pengalaman industri yang terbatas. Pengalaman industri yang terbatas ini, membuat guru kejuruan lebih berorientasi pada buku teks, lebih akademik, sehingga cenderung pola pembelajaran yang ditonjolkan lebih bersifat teoretis. Rosenshine dan Furst (1971) menulis tentang pengajaran yang efektif mengidentifikasi 11 indikator, yaitu: (1) Clarity (kejelasan), (2) Variability (variabelitas), (3) Enthusiasm (enthusias), (4) Personal Efficiency, (5) Opportunity to Learn (kesempatan belajar), (6) Accepting and Encouraging (penerimaan dan ajakan), (7) Use of Criticism (menggunakan kritik), (8) Use of Structure and Summary Comments, menggunakan komentar yang menarik minat belajar siswa, (9) Question Technique (teknik bertanya), (10) Probing (mencari), dan (11) Difficulty Level of Instructions (tingkat kesulitan pembelajaran). Kesebelas indikator tersebut diidentifikasi dengan me-review proses dan pencapaian hasil belajar siswa. Instrumen ini lebih lanjut dikembangkan oleh Cheffers dan Sullivan (2000). Penyesuaian dengan kinerja guru kejuruan memperkaya butir instrumen dengan tugas kejuruan dalam pengajaran di workshop, labora-torium, studio, maupun pada saat siswa melaksanakan magang atau praktik industri di dunia kerja.

Sudah cukup banyak dana yang dikeluarkan untuk program sertifikasi guru, bila rata-rata setiap guru menghabiskan dana Rp 2.000.000,00 per orang, maka telah dihabiskan dana hampir 70 miliar rupiah. Penelitian ini men-coba mengkaji sejauh mana dampak program sertifikasi guru ini terhadap kinerja guru di sekolah, sekaligus melihat dampaknya terhadap kehidupan guru di masyarakat, terutama terkait dengan tingkat kesejahteraan guru. Apakah program sertifikasi guru telah meningkatkan kinerja guru dan tingkat kesejahteraan guru? Harapan lebih jauh adalah program tersebut berdampak terhadap peningkatan kualitas pendidikan untuk menciptakan insan Indonesia yang cerdas dan kompetitif.

Oleh karena itu, evaluasi kinerja guru SMK pascasertifikasi guru dapat dijadikan sebagai pertimbangan untuk menentukan ketercapaian tujuan sertifikasi untuk meningkatkan mutu pendidikan. Implementasi dan 
dampak terhadap peningkatkan kinerja guru. Inti dari evaluasi adalah penyediaan informasi yang dapat dijadikan sebagai bahan pertimbangan dalam mengambil keputusan. Komite Studi Nasional tentang Evaluasi (National Study Committee on Evaluation) dari UCLA (Stark \& Thomas, 1994:12) menyatakan "Evaluation is the process of ascertaining the decision of concern, selecting appropriate information, and collecting and analyzing information in order to report summary data useful to decision makers in selecting among alternatives". Evaluasi merupakan suatu proses atau kegiatan pemilihan, pengumpulan, analisis dan penyajian informasi yang dapat digunakan sebagai dasar pengambilan keputusan serta penyusunan program selanjutnya. Dengan melakukan evaluasi ini, hasilnya dapat digunakan sebagai referensi pengembangan kinerja guru kejuruan berikutnya.

Terkait dengan hal tersebut, tujuan penelitian ini adalah mengetahui (1) kualifikasi guru SMK Sumatera Barat, (2) tingkat capaian kinerja guru SMK Sumatera Barat, dan (3) kinerja guru SMK Sumatera Barat pascasertifikasi terhadap peningkatan kualitas pendidikan secara nasional.

\section{Metode Penelitian}

Penelitian ini menggunakan metode deskriptif kuantitatif dengan pendekatan survei yang dilakukan untuk menyelidiki kinerja guru pascasertifikasi. Populasi meliputi semua guru teknologi dan kejuruan di Sumatera Barat, kemudian dilakukan cluster random sampling terhadap SMK yang ada di kota atau di kabupaten. Clustering dilakukan dengan menyeleksi empat kota, yang keempat kota tersebut diasumsikan mewakili kriteria SMK di Sumatera Barat. Kempat kota yang terseleksi adalah Kota Padang, Kota Payakumbuh, Kota Bukittinggi dan Kota Pariaman. Dari semua SMK Negeri pada keempat kota tersebut ditetapkan 10 SMK dengan jumlah guru tersertifikasi sebanyak 974 orang, kemudian diambil 25\% sebagai sampel penelitian sebanyak 247 orang guru.

Data dikumpulkan dengan menggunakan angket yang terdiri atas 2 bagian yaitu (1) informasi biodata guru berkaitan dengan pengembangan profesional guru setelah program sertifikasi, (2) instrumen kinerja guru dengan model skala Likert yang dikembangkan atas dasar instrumen yang 
dikembangkan oleh Cheffers \& Sullivan. Instrumen ini diadaptasikan sesuai dengan tugas dan tanggung jawab guru teknologi dan kejuruan, sehingga diharapkan mampu menggambarkan kinerja guru kejuruan. Instrumen ini diuji coba terlebih dahulu untuk mengetahui kualitasnya dengan responden sebanyak 30 orang. Estimasi reliabilitas dilakukan menggunakan rumus Alhpa dari Cronbach. Hasil estimasi reliabilitas menunjukkan bahwa koefisien reliabi-litas sebesar 0,94 . Kriteria yang digunakan untuk menetapkan reliabilitas instrumen adalah jika koefisien reliabilitas lebih besar atau sama dengan 0,50 (Gay, 1980).

Analisis data yang dilakukan yaitu analisis deskriptif untuk menjelaskan tentang skor kinerja guru yang diperoleh membandingkan dengan skor rata-rata pengukuran. Apabila skor kinerja guru di atas skor rata-rata hasil pengukuran, berarti SMK itu mempunyai kinerja guru yang baik. Sebaliknya, apabila skor kinerja guru di bawah skor rata-rata hasil pengukuran, berarti kinerja guru di SMK kurang baik.

Semua data dikelompokkan berdasarkan jenis data dan diolah secara statistik dengan menggunakan SPSS. Data penunjang dari informasi pimpinan sekolah, siswa, dan komite sekolah akan dijadikan referensi dalam pembahasan hasil penelitian.

\section{Hasil dan Pembahasan}

Berdasarkan hasil analisis data, temuan penelitian menunjukkan bahwa sebagian besar 85,43 \% tingkat pendidikan guru SMK telah menyelesaikan S1, bahkan sebanyak 14,57 \% telah berpendidikan S2, sebagaimana ditunjukkan pada Tabel 1.

Tabel 1. Distribusi Frekuensi Guru SMK Berdasarkan Jenjang Pendidikan

\begin{tabular}{cccc}
\hline No. & Jenjang Pendidikan & Frekuensi & Persen $(\%)$ \\
\hline 1 & S1 Non Kependidikan & 18 & 7,29 \\
2 & S1 Pendidikan Teknik & 193 & 78,14 \\
3 & S2 Non Kependidikan & 10 & 4,05 \\
4 & S2 Pendidikan & 26 & 10,52 \\
& Total & 247 & 100,00 \\
\hline
\end{tabular}

\footnotetext{
Pengembangan Model Evaluasi Kinerja SD - 79 Ramli, Nizwardi Jalinus
} 
Bila ditelaah keadaan guru SMK yang berbasis pendidikan teknologi dan kejuruan, dengan dasar kualifikasi minimal pendidikan S1 atau diploma IV Program Studi Pendidikan Teknik dan Kejuruan, bahkan sebagian telah mendapatkan pendidikan Magister Pendidikan, hal ini menunjukkan bahwa secara umum guru SMK telah memenuhi kriteria UU No. 14 Tahun 2005. Dalam UU tersebut guru minimal berkualifikasi S1 atau Diploma IV.

Kemudian sebagai guru yang berstatus guru tetap Pegawai Negeri Sipil (PNS) dan telah tersertifikasi, sebagian besar telah memperoleh beban mengajar yang relatif sesuai dengan beban yang ditetapkan pemerintah yaitu 24 jam tatap muka yang secara terinci disajikan pada Tabel 2.

Tabel 2. Distribusi Frekuensi Guru Berdasarkan Beban Mengajar

\begin{tabular}{cccc}
\hline No & Beban Mengajar & Frekuensi & Persen $(\%)$ \\
\hline 1 & $>24$ jam & 24 & 9,7 \\
2 & $>30$ jam & 2 & 0,8 \\
3 & 24 jam & 183 & 74,1 \\
4 & $25-30$ jam & 38 & 15,4 \\
& Total & 247 & 100,00 \\
\hline
\end{tabular}

Pada Tabel 2, dapat dilihat bahwa keadaan ini memungkinkan guru untuk memiliki kinerja optimal, bila beban kerja tersebut diimplementasikan dengan efektif dan efisien. Suasana setelah memperoleh sertifikasi yang bermakna pengakuan terhadap profesi pendidik yang telah ditempuh berdasarkan portofolio atau melalui PLPG dan Uji Kompetensi Guru, selayaknya menimbulkan suatu motivasi baru bagi guru untuk melaksanakan tugas dengan dedikasi dan komitmen yang tinggi, apalagi status pendidik profesional mendapat tunjangan profesi sebesar satu kali gaji pokok. Analogi ini akan berdampak terhadap peningkatan kinerja guru. Peningkatan kinerja guru selayaknya berdampak terhadap prestasi belajar siswa, dan bermuara pada meningkatnya mutu pendidikan teknologi dan kejuruan secara nasional. 
Selanjutnya, tingkat capaian skor kinerja guru SMK diperoleh 77,21\% dari skor ideal, berada pada kategori cukup baik. Berdasarkan data ini dapat dikatakan bahwa kinerja guru di sekolah kejuruan pada umumnya berada pada kategori cukup (Tabel 3). Berdasarkan temuan penelitian ini, dapat diperoleh bahwa pertama, kinerja guru masih sedang-sedang saja atau dalam kategori cukup yang cenderung kearah baik (capaian 77,21\%); kedua, ada 4 indikator terkategori kurang baik, yaitu: (1) indikator acception and encouraging (penerimaan dan ajakan), guru selalu menerima, mengajak dan mendengar siswanya, maknanya adalah guru hendaknya bersikap menerima, mengajak, mengayomi siswanya, selalu mendengar keluhan dan kebutuhan siswanya, nampaknya kategori ini masih memberikan respon yang kurang baik; (2) indikator use of criticism (menggunakan kritik) guru belum terbiasa untuk dapat menerima kritik dari siswa, hal ini untuk mengontrol kelas, apakah kegiatan pembelajaran telah berlangsung dengan efektif nampaknya kategori ini masih kurang baik; (3) indikator difficulty level of instructions (tingkat kesulitan pembelajaran), yang menantang siswa untuk berusaha mencapai tingkat kesulitan pembelajaran yang berlangsung, nampaknya kategori ini masih memberikan respon yang kurang baik dikerjakan guru, dan (4) indikator terkait dengan usaha guru untuk meningkatkan kualitas pembelajaran melalui penelitian tindakan kelas masuk kategori kurang baik.

Sementara itu, beberapa indikator lainnya seperti clarity (kejelasan), variability (variabilitas), enthusiasm (enthusias), personal effisiensi, opportunity to learn (kesempatan untuk belajar), telah berkategori baik dan sangat baik. Sebagian lainnya seperti perilaku dan karakter guru atau terkait dengan kompetensi kepribadian guru masih dalam kategori cukup dengan kecendrungan baik. Guru dalam memberikan kesempatan kepada siswa untuk menguasai pelajaran, membantu siswa dalam proses pembelajaran dalam penggunaan waktu yang tepat, penggunaan teknik bertanya dan pertanyaan yang menyelidik melihat kedalaman penguasaan siswa terhadap materi yang disajikan, dan persiapan perencanaan, dan pelaksanaan praktik, serta evaluasi pembelajaran praktik di workshop ataupun laboratorium, masih cenderung masuk kategori cukup. Seharusnya setelah program sertifikasi hal itu menjadi lebih baik dan sangat baik. 
Tabel 3. Skor Kinerja Guru Kejuruan

\begin{tabular}{|c|c|c|c|c|c|c|c|c|c|c|c|c|}
\hline \multirow{3}{*}{ No } & \multirow{3}{*}{ Indikator } & \multicolumn{8}{|c|}{ Kriteria Pernyataan } & \multirow{3}{*}{$\begin{array}{l}\text { Rata- } \\
\text { rata } \\
\text { Skor }\end{array}$} & \multirow{3}{*}{$\begin{array}{c}\text { Tingkat } \\
\text { Capaian } \\
(\%)\end{array}$} & \multirow{3}{*}{ Ket } \\
\hline & & \multicolumn{2}{|c|}{ Selalu } & \multicolumn{2}{|c|}{ Sering } & \multicolumn{2}{|c|}{$\begin{array}{l}\text { Kadang- } \\
\text { Kadang }\end{array}$} & \multicolumn{2}{|c|}{ Jarang } & & & \\
\hline & & $\mathrm{F}$ & $\%$ & $\mathrm{~F}$ & $\%$ & $\mathrm{~F}$ & $\%$ & $\mathrm{~F}$ & $\%$ & & & \\
\hline 1 & Butir 1 & 164 & 66,40 & 72 & 29,15 & 10 & 4,05 & 1 & 0,40 & 3,62 & 90,38 & $\begin{array}{c}\text { Sangat } \\
\text { baik }\end{array}$ \\
\hline 2 & Butir 2 & 147 & 59,51 & 81 & 32,79 & 18 & 7,29 & 1 & 0,40 & 3,51 & 87,85 & Baik \\
\hline 3 & Butir 3 & 107 & 43,32 & 108 & 43,72 & 30 & 12,15 & 2 & 0,81 & 3,30 & 82,39 & Baik \\
\hline 4 & Butir 4 & 95 & 38,46 & 111 & 44,94 & 39 & 15,79 & 2 & 0,81 & 3,21 & 80,26 & Baik \\
\hline 5 & Butir 5 & 84 & 34,01 & 107 & 43,32 & 53 & 21,46 & 3 & 1,21 & 3,10 & 77,53 & Cukup \\
\hline 6 & Butir 6 & 93 & 37,65 & 131 & 53,04 & 21 & 8,50 & 2 & 0,81 & 3,28 & 81,88 & Baik \\
\hline 7 & Butir 7 & 110 & 44,53 & 112 & 45,34 & 24 & 9,72 & 1 & 0,40 & 3,34 & 83,50 & Baik \\
\hline 8 & Butir 8 & 118 & 47,77 & 103 & 41,70 & 25 & 10,12 & 1 & 0,40 & 3,37 & 84,21 & Baik \\
\hline 9 & Butir 9 & 126 & 51,01 & 103 & 41,70 & 18 & 7,29 & 0 & 0,00 & 3,44 & 85,93 & Baik \\
\hline 10 & Butir 10 & 90 & 36,44 & 115 & 46,56 & 40 & 16,19 & 2 & 0,81 & 3,19 & 79,66 & Cukup \\
\hline 11 & Butir 11 & 35 & 14,17 & 91 & 36,84 & 99 & 40,08 & 22 & 8,91 & 2,56 & 64,07 & Kurang \\
\hline 12 & Butir 12 & 40 & 16,19 & 64 & 25,91 & 70 & 28,34 & 73 & 29,55 & 2,29 & 57,19 & Kurang \\
\hline 13 & Butir 13 & 48 & 19,43 & 134 & 54,25 & 62 & 25,10 & 3 & 1,21 & 2,92 & 72,98 & Cukup \\
\hline 14 & Butir 14 & 75 & 30,36 & 140 & 56,68 & 30 & 12,15 & 2 & 0,81 & 3,17 & 79,15 & Cukup \\
\hline 15 & Butir 15 & 45 & 18,22 & 115 & 46,56 & 81 & 32,79 & 6 & 2,43 & 2,81 & 70.14 & Cukup \\
\hline 16 & Butir 16 & 21 & 8,50 & 100 & 40,49 & 124 & 50,20 & 2 & 0,81 & 2,57 & 64,17 & Kurang \\
\hline 17 & Butir 17 & 108 & 43,72 & 87 & 35,22 & 44 & 17,81 & 8 & 3,24 & 3,19 & 79,86 & Cukup \\
\hline 18 & Butir 18 & 150 & 60,73 & 57 & 23,08 & 31 & 12,55 & 9 & 3,64 & 3,41 & 85,22 & Baik \\
\hline 19 & Butir 19 & 117 & 47,37 & 71 & 28,74 & 47 & 19,03 & 12 & 4,86 & 3,19 & 79,66 & Cukup \\
\hline 20 & Butir 20 & 18 & 7,29 & 72 & 29,15 & 130 & 52,63 & 27 & 10,93 & 2,33 & 58,20 & Kurang \\
\hline & & & & Rat & ata & & & & & 3,09 & 77,21 & Cukup \\
\hline
\end{tabular}

Selayaknya guru teknologi dan kejuruan menyadari bahwa tanggung jawab yang dibebankan pemerintah dan rakyat adalah suatu tanggung jawab yang membutuhkan motivasi dan komitmen yang tinggi, untuk terselenggaranya pendidikan dan pelatihan yang bermutu. Tunjangan profesi sebesar satu kali gaji pokok, sebagai imbalan guru profesional seharusnya tidak dipandang sebagai segala-galanya, karena berapapun besarnya tam- 
bahan tunjangan yang diterima, sebenarnya tidak seberapa dibanding pengorbanan yang dilakukan oleh guru untuk melakukan pendidikan untuk anak didiknya dengan keikhlasan. Kembali ke khitah guru yang selalu bangga dengan keberhasilan anak didiknya, adalah perubahan sikap guru yang dibutuhkan oleh bangsa ini. Bukan berapa besar tunjangan yang diterima tetapi berapa besar keikhlasan guru membuat anak-didiknya berprestasi.

Sekolah hendaknya memberi ruang bagi guru untuk berimprovisasi, berinovasi, terus menerus belajar, untuk selalu beradaptasi terhadap perubahan, baik perubahan teknologi yang demikian cepat, maupun perubahan sosial-budaya dan ekonomi, yang akan berdampak terhadap proses pendidikan dan pembelajaran. Pimpinan sekolah apakah itu kepala sekolah, pengawas (supervisor), ataupun dinas-dinas pendidikan yang selalu mengembangkan kebijakan-kebijakan pendidikan di tingkat pusat ataupun daerah, perlu mengantisipasi berbagai perubahan pendidikan khususnya pendidikan teknologi dan kejuruan, mendukung, memotivasi, dan memfasilitasi berbagai usaha pengembangan guru pendidikan teknologi dan kejuruan sesuai dengan dinamika perubahan pendidikan itu sendiri.

Mengkaji permasalahan yang masih dialami oleh guru kejuruan, maka usaha untuk meningkatkan kinerja ini harus dilakukan terus menerus dan melalui berbagai upaya. Kategori yang masih kurang baik sebagaimana sebaiknya menjadi perhatian utama untuk diperbaiki, terutama melalui perbaikan motivasi guru untuk memberikan pelayanan optimal kepada siswanya, memberikan ruang kepada siswa untuk belajar mengkritik, agar dapat menguasai kompetensi lebih baik. Sebagaimana diungkapkan Biggs \& Moore (1993), bahwa umumnya siswa hanya berkesempatan belajar dipermukaan (surface learning), seharusnya mereka menyelam sehingga terjadi proses belajar yang intensitasnya tinggi (deep learning). Begitu pula dalam usaha meningkatkan kualitas pembelajaran guru hendaknya aktif melakukan penelitian tindakan kelas, mencoba melakukan perbaikan pembelajaran dengan model pembelajaran yang bervariasi, melakukan inovasi agar pembelajaran menjadi efektif dan efisien. Kegiatan ini masih kurang dilaksanakan oleh guru kejuruan. 
Kegiatan praktik di workshop, laboratorium atau studio, belum diselenggarakan dengan optimal, masih dalam kategori cukup, padahal kompetensi produktif yang dituntut dunia kerja sebagaimana tertera dalam kurikulum bahwa inti pembelajaran di sekolah kejuruan adalah penguasaan kompetensi produktif, dengan harapan bila kompetensi produktif yang dikuasai siswa memadai, maka kesempatan bagi lulusan SMK memasuki dunia kerja menjadi lebih terbuka. Kritik dunia kerja terhadap lulusan SMK di antaranya adalah rendahnya mutu kompetensi produktif yang dikuasai siswa. Hal ini akan menyulitkan siswa untuk bersaing mendapatkan pekerjaan yang sesuai dengan bidangnya.

Secara kumulatif indikator yang masih berada pada kategori kurang baik ataupun cukup mempengaruhi performa guru, sehingga penilaian kinerja guru kejuruan ini belum mencapai hasil seperti yang diharapkan. Setelah enam tahun, penyelenggaraan sertifikasi guru ternyata belum berdampak optimal terhadap kinerja guru kejuruan di lapangan. Berbagai indikator yang belum optimal yang ditemukan dalam penelitian ini perlu menjadi perhatian berbagai pihak, baik itu pimpinan sekolah, dinas pendidikan dan kebudayaan, pemerintah dan lembaga penyelenggara sertifikasi, termasuk LPTK dan LPMP, maupun lembaga penyelenggara pendidikan dan pelatihan guru kejuruan dan teknologi. Program pembinaan, pendidikan dan pelatihan guru kejuruan secara terus menerus perlu diselenggarakan (Continues Teachers Development programs). Para guru kejuruan juga mengungkapkan bahwa mereka membutuhkan pengembangan diri melalui berbagai kegiatan pengembangan diri, dan hal itu adalah bagian kegiatan yang sangat penting bagi perkembangan profesi guru kejuruan.

Program PLPG yang lamanya hanya 10 hari dan efektifnya 9 hari, barangkali sebagai pemicu motivasi dan menanamkan komitmen guru profesional barangkali cukup, namun banyak dari materi yang disajikan belum termanfaatkan dalam pekerjaan sehari-hari guru di sekolah. Misalnya saja peer teaching untuk pembelajaran di workshop dan laboratorium, kurang difokuskan untuk guru kejuruan. Tampaknya sebagian hanya berfokus pada pembelajaran dalam kelas. Hal ini jelas dalam program PLPG memang tidak dipersiapkan untuk pembelajaran dalam praktikum di workshop dan laboratorium (barangkali karena biaya praktik memang mahal, perlu mem- 
beli bahan praktik, penggunaan mesin dan alat dan lain-lain). Fasilitas ini tidak disediakan oleh penyelenggara. Materi penelitian tindakan kelas tidak ada tindak lanjut di sekolah, tidak ada ruang yang disediakan untuk itu, sehingga pekerjaan inipun tidak dilakukan $\mathrm{Hal}$ ini juga yang mengurangi intensitas kinerja guru.

\section{Simpulan dan Saran}

Berdasarkan hasil penelitian dan pembahasan, dapat disimpulkan sebagai berikut: (1) keadaan guru teknologi dan kejuruan pada umumnya telah berkualifikasi pendidikan sesuai dengan perundang-undangan, bahkan cukup banyak berkualifikasi S2, (2) mayoritas guru teknologi kejuruan tersebut mendapat beban mengajar sesuai dengan aturan yang berlaku yaitu 24 jam tatap muka per minggu, didukung statusnya sebagai Pegawai Negeri Sipil, mereka telah mendapatkan tunjangan profesi, dan (3) kinerja guru pascasertifikasi ternyata belum berkembang seperti yang diharapkan, masih dalam kategori cukup, bahkan pada beberapa indikator ada yang kurang di antaranya adalah usaha guru untuk dapat menerima masukan siswa dan encouraging (mengajak) siswa untuk menguasai lebih dalam kompetensi yang diharapkan, menerima kritik siswa dan usaha mengontrol kelas, merespon tantangan dengan tingkat kesulitan materi, serta usaha untuk pelaksanaan penelitian tindakan kelas.

Seiring dengan simpulan, dikemukakan saran-saran sebagai berikut (1) pimpinan SMK perlu membuat peta kualitas guru teknologi dan kejuruan, agar gambaran kekuatan dan kekurangan setiap guru teknologi dan kejuruan terinventaris, sebagai bahan untuk pengembangan staf yang terus menerus, (2) guru SMK hendaknya selalu berupaya untuk meningkatkan kinerjanya secara sadar dan ikhlas, belajar mengenali diri, memahami kekurangan, dan berbagi dengan kolega guru lainnya bila ada kelebihan, berusaha untuk terus mengembangkan diri, memahami proses pembelajaran siswa, menerima kritik, berbuat yang terbaik untuk siswa di kelas, maupun di workshop, (3) dinas pendidikan selayaknya menyediakan fasilitas untuk guru kejuruan yang mau melaksanakan penelitian tindakan kelas, internship ke dunia kerja (industrial attachment), termasuk mengelola admi- 
nistrasi tunjangan belajar yang efektif dan efisien, dan (4) badan penjaminan mutu pendidik dan LPTK sebagai lembaga pelaksana program sertifikasi agar menyeimbangkan isi program PLPG antara program yang mengutamakan kompetensi pedagogi, penguasaan materi dengan perubahan perilaku guru, agar lebih terbuka terhadap kritik siswa, lebih kreatif, inovatif dan adaptif terhadap perubahan.

\section{Daftar Pustaka}

Bernardin, H.J., \& Russell, J.E.A. (2000). Human Resources Management. New York: Mc-Graw Hill.

Biggs, J.B., \& Moore, P.J. (1993). The Process of Learning. Thrid Edition. Sydney: Prentice Hall.

Cheffers \& Sullivan. (2000). Teachers Performance Criteria Questionares (TPQC).

Gay, L.R. (1980). Educational Evaluation and Measurement. Columbus, Ohio: Carles Publishing Company.

Jalal, Fasli. (2007). Sertifikasi Guru Untuk Menujudkan Pendidikan yang Bermutu? Makalah disampaikan pada seminar pendidikan yang diselenggarakan oleh Program Pascasarjana Unair, tanggal 28 April 2007 di Surabaya.

Nawawi, Hadari. (1996). Administrasi Pendidikan. Jakarta: PT. Gunung Agung, Cet. Ke-1.

Permendiknas No. 41 Tahun 2007 tentang Standar Proses. Jakarta: Departemen Pendidikan Nasional.

Ramli. (2012). Pengaruh Budaya Sekolah, Kinerja Guru dan Motivasi Belajar terbadap Kompetensi Produktif Siswa SMK Sumatera Barat. Padang: Disertasi.

86 - Jurnal Penelitian dan Evaluasi Pendidikan Tahun 17, Nomor 1, 2013 
Rosenshine, B., \& Furst, N. (1971). Research in teacher performance criteria. In B. O. Smith (Ed.), Symposium on research in teacher education. Englewood Cliffs, NJ: Prentice Hall.

Stark, J.S. \& Thomas, A. (1994). Assessment and Program Evaluation. Needham Heights: Simon \& Schuster Custom Publishing.

Subroto, Suryo. (1997). Proses Pembelajaran. Jakarta: Rineka Cipta. Cet. Ke-1.

Undang-Undang No. 20 Tahun 2003 tentang Sistem Pendidikan Nasional. Jakarta: Departemen Pendidikan Nasional.

Undang-Undang No 14 tahun 2005 Tentang Guru dan Dosen. Jakarta: Departemen Pendidikan Nasional. 